University of Nebraska - Lincoln

DigitalCommons@University of Nebraska - Lincoln

October 1995

\title{
Growth of Testes and Testicular Morphology After Eight Generations of Selection for Increased Predicted Weight of Testes at 150 Days of Age in Boars
}

\author{
R. R. Harder \\ University of Nebraska-Lincoln \\ D. D. Lunstra \\ University of Nebraska-Lincoln \\ R. K. Johnson \\ University of Nebraska-Lincoln, rjohnson5@unl.edu \\ Roman L. Hruska \\ US. Meat Animal Research Center, USDA-ARS, Clay Center, NE
}

Follow this and additional works at: https://digitalcommons.unl.edu/animalscifacpub

Part of the Animal Sciences Commons

Harder, R. R.; Lunstra, D. D.; Johnson, R. K.; and Hruska, Roman L., "Growth of Testes and Testicular Morphology After Eight Generations of Selection for Increased Predicted Weight of Testes at 150 Days of Age in Boars" (1995). Faculty Papers and Publications in Animal Science. 53.

https://digitalcommons.unl.edu/animalscifacpub/53

This Article is brought to you for free and open access by the Animal Science Department at DigitalCommons@University of Nebraska - Lincoln. It has been accepted for inclusion in Faculty Papers and Publications in Animal Science by an authorized administrator of DigitalCommons@University of Nebraska - Lincoln. 


\title{
Growth of Testes and Testicular Morphology After Eight Generations of Selection for Increased Predicted Weight of Testes at 150 Days of Age in Boars ${ }^{1,2}$
}

\author{
R. R. Harder 3 , D. D. Lunstra, and R. K. Johnson \\ Department of Animal Science, University of Nebraska, Lincoln 68583-0908 and Roman L. Hruska \\ U.S. Meat Animal Research Center, ARS, USDA, Clay Center, NE 68933
}

\begin{abstract}
Weights of testes and epididymides, body weight, and morphometric measurements of testicular tissue of 75 boars of a line selected for eight generations for predicted weight of testes at $150 \mathrm{~d}$ of age and 75 boars of a randomly selected control line were used to evaluate the effects of selection on testicular development at 70,100,130,160, and $450 \mathrm{~d}$ of age ( $n=15$ boars per line per age). Body weights for boars of the select and control line did not differ ( $P$ $<.05$ ) and the shape of the body growth curve was similar for both lines. Boars of the select line had larger testes than control boars at each age $(P<.05)$, but there was a significant line $\times$ age interaction. The percentage increase of the select line mean over the control mean for weight of testes was $37 \%$ at $70 \mathrm{~d}$, a maximum of $120 \%$ at $100 \mathrm{~d}$, and $25 \%$ at $450 \mathrm{~d}$. The
\end{abstract}

percentage of the testes made up of seminiferous tubules differed between lines $(P<.01)$. Lines had similar means of approximately $28 \%$ at $70 \mathrm{~d}$ and $71 \%$ at $450 \mathrm{~d}$, but the mean for the select line was larger between 100 and $160 \mathrm{~d}$ of age; the greatest difference was $11.6 \%$ (control $=43.7$, select $=55.3 \%$ ) at $100 \mathrm{~d}$. After $70 \mathrm{~d}$ of age, select-line boars had a greater percentage of seminiferous tubules with lumens that contained elongated spermatids ( $P<.10$ ). The proportion of the testes occupied by Leydig cells was greatest at $70 \mathrm{~d}$, declined sharply between 70 and $130 \mathrm{~d}$ with a sharper decline in select-line boars, and then declined more gradually from 130 to $450 \mathrm{~d}$ of age. We conclude that selection for weight of testes at $150 \mathrm{~d}$ resulted in lower age at puberty for boars of the select line.

Key Words: Pigs, Selection, Testes, Seminiferous Tubules, Leydig Cells

J. Anim. Sci. 1995. 73:2186-2192

\section{Introduction}

Genetic improvement of reproductive efficiency of boars would improve efficiency of pork production. However, traits of boars such as age at puberty, rates of sperm production, and mating capabilities are difficult to measure and are expressed after selection decisions for growth, fat, and female reproductive traits have been made. Therefore, effective selection for male reproductive traits is not possible within current industry testing and selection practices.

Selection response could be enhanced by selecting for a moderately heritable indicator trait that is correlated with the important traits. Size of testes might be such a trait. It has been found to be positively correlated with sperm output and semen

\footnotetext{
${ }^{1}$ Published as paper no. 10629, Journal Ser., Nebraska Agric. Res. Div., Univ, of Nebraska, Lincoln 68583-0908.

${ }^{2}$ Acknowledgments to Alan Kruger for technical expertise.

${ }^{3}$ Current address: 513 Garden, Ames, IA 50010.

Received February 24, 1994.

Accepted March 8, 1995.
}

quality in young bulls (Lunstra et al., 1978; Coulter and Foote, 1979; Gipson et al., 1985). Lunstra et al. (1978) reported that scrotal circumference is a measure of age at puberty in bulls. However, Haley et al. (1990), found rams of lines selected for increased and decreased size of testes adjusted for body weight did not differ in fertility.

Weight of testes at a constant age may be a useful indicator trait to select for increased reproductive efficiency of boars. Johnson et al. (1994) found the realized heritability of predicted weight of paired testes at $150 \mathrm{~d}$ was .35 and the response per generation averaged $5.5 \%$ of the base generation mean. Rathje et al. (1995) found boars from the select line had heavier testes from 70 to $450 \mathrm{~d}$ of age, produced more sperm per gram of testicular tissue, and produced more sperm cells than control boars.

The objectives of this study were to characterize the morphology of the testes of boars of the select and the control lines from 70 to $450 \mathrm{~d}$ of age and to determine whether selection for predicted weight of testes at 150 $\mathrm{d}$ decreased age at puberty as measured by seminiferous tubule development and the presence of spermatids in tubules. 


\section{Materials and Methods}

Populations. Ten generations of selection for increased predicted weight of paired testes at $150 \mathrm{~d}$ of age (TS line) or random selection (C line) were practiced. The design of the experiment, direct response in the selected trait and correlated responses in body weight and backfat of boars and gilts, and age at puberty of gilts were reported by Johnson et al. (1994).

Mass selection among boars was practiced in line TS and random selection within families in line $\mathrm{C}$. Both lines were maintained with 40 to 45 litters by 15 boars per generation. Weight of paired testes at $150 \mathrm{~d}$ of age was predicted from measurements of width and length of testes at 140 and $160 \mathrm{~d}$ of age. Based on data collected in boars from the same population before the experiment began, the correlation between predicted weight and actual weight of paired testes was calculated to be .92 .

Experimental Procedure. A sample of 150 boars ( 75 per line) from Generation 8 was used for this experiment. Diets fed to the boars, procedures for measuring testes, and general management of the boars are described by Johnson et al. (1994).

While in the nursery, five boars from each of the $\mathbf{1 5}$ paternal half-sib families of each line were selected randomly. These boars were randomly assigned within half-sib family to be castrated at ages of $70,100,130$, 160 , or $450 \mathrm{~d}$ with 15 boars assigned to each line-age subclass. Therefore, a split-plot design that incorporated randomized complete blocks was used. Half-sib families were the blocks, treatments were arranged factorially with selection line as the main plot treatment, and age as the subplot treatment.

At approximately $56 \mathrm{~d}$ of age, boars were moved to a naturally ventilated building. There were 9 or 10 pigs of similar age in each pen. They had available on an ad libitum basis a diet of corn, soybean meal, and premix calculated to contain $16 \%$ protein until the average weight of boars in a pen was approximately $60 \mathrm{~kg}$ and a diet formulated to contain $14 \%$ protein thereafter. Each boar was removed from its pen and castrated when it reached the treatment age to which it had been assigned. Boars in the 450-d treatment were moved from their pen to outside dirt lots at approximately 7 mo of age. They remained in this lot until they were castrated. During this time, they were fed approximately $2.3 \mathrm{~kg} / \mathrm{d}$ of the $14 \%$ protein diet.

Castration and Tissue Fixation. Each boar was weighed just before it was castrated. Anesthesia was induced with sodium pentothal (biotal; $2.5 \% \mathrm{wt} / \mathrm{vol}$, aqueous, i.v.) administered via an ear vein. Testes and epididymides were surgically removed. The left testis and epididymis were trimmed free of exterior tissue and weighed.

The right testis was immediately perfused via the testicular artery using a modification of the procedure described by Lunstra et al. (1986). Perfusion was initiated with approximately $50 \mathrm{~mL}$ of $.1 M$ sodium cacodylate buffer ( $\mathrm{pH}=7.4$ ) to clear the blood from the vascular system. A three-way valve was used to stop the flow of buffer and simultaneously begin the flow of $3 \%$ glutaraldehyde $/ 1 \%$ formaldehyde fixative in $.075 M$ sodium cacodylate buffer (Glauert, 1975). Perfusion continued until the volume of fixative infused was approximately twice the weight of the testis.

Subsections ( $2 \mathrm{~mm} \times 2 \mathrm{~mm} \times 4 \mathrm{~mm}$ ) of parenchyma were obtained from the proximal, medial, and distal regions of the perfused testis. Each subsection was divided in half and both halves were placed in a vial containing $5 \mathrm{~mL}$ of fresh fixative. Vials were capped, placed on ice, and transported to the laboratory where they were placed on a rotator overnight at a temperature of $4^{\circ} \mathrm{C}$.

The following day, the fixative was removed from the vials and tissue samples were immediately submerged in $.1 \mathrm{M}$ sodium cacodylate buffer at $4^{\circ} \mathrm{C}$ for 15 min. The buffer solution was removed and tissues were postfixed with $1 \%$ osmium tetroxide in $.075 \mathrm{M}$ cacodylate buffer $\left(4^{\circ} \mathrm{C}\right)$ on a rotator for $2 \mathrm{~h}$. The tissues were then rinsed twice in buffer, dehydrated in graded $(50,70,80,95$, and $100 \%)$ ethanol, solventexchanged twice in $100 \%$ propylene oxide, infiltrated for $2 \mathrm{~h}$ with a 1:1 mixture of propylene oxide and LuftAraldite 502 resin mixture, and embedded in Araldite 502 resin mixture (4:3 ratio of Araldite 502/dodecenylsuccinic anhydride; Luft, 1961). Embedded samples were placed in ovens for $12 \mathrm{~h}$ at $35^{\circ} \mathrm{C}, 24 \mathrm{~h}$ at $45^{\circ} \mathrm{C}$, and $24 \mathrm{~h}$ at $60^{\circ} \mathrm{C}$ for polymerization.

Morphometric Procedures. Johnson and Neaves (1981) reported that this type of embedding procedure caused negligible tissue shrinkage in embedded samples. Therefore, no correction for tissue shrinkage was used. Lunstra et al. (1986) reported no significant differences existed in size or ultrastructure of Leydig cells obtained from different regions of the boar testis. Therefore, polymerized samples from the medial portion of the testis were used for light microscopy measurements.

Thick slices ( 2 microns) were cut from the polymerized tissue samples using glass knives mounted on a microtome. Slices were mounted on glass slides and stained with $1 \%$ periodic acid, $1 \%$ toluidine-blue, and $.5 \%$ basic fuchsin solutions (Sato and Shamoto, 1973). Two slides from each sample were placed in $1 \%$ periodic acid for $2 \mathrm{~min}$ at $50^{\circ} \mathrm{C}$, rinsed five times under warm running tap water, and rinsed three times under deionized tap water. After drying, slides were immersed in $1 \%$ toluidine-blue mixture for $5 \mathrm{~min}$ at $50^{\circ} \mathrm{C}$, rinsed again as described above, and immersed in $.5 \%$ basic-fuchsin mixture for $4 \mathrm{~min}$ at $50^{\circ} \mathrm{C}$. After a final series of rinses, stained sections were dried thoroughly on a $60^{\circ} \mathrm{C}$ slidewarmer for $1 \mathrm{~h}$.

Two to four subsections from each of two blocks of embedded tissue were evaluated for each boar. Sections with tears or folds were not used. Average values 
for these sections for each boar were analyzed.

All measurements were made under 100 total magnification using computerized morphometric planimetry (Bioquant II System, R \& M Biometrics, Nashville, TN). The image of each section was projected onto a computer screen and major morphological structures were measured by tracing outlines with a computer mouse connected to a digital pad. Measurements taken included area of whole seminiferous tubules with lumens, area of partial seminiferous tubules with lumens, area of whole seminiferous tubules without lumens, area of partial tubules without lumens, and area occupied by vasculature, which included both lymphatic and blood vessels. Subtraction of the sum of these areas from the total area was used to determine the area of the sample occupied by Leydig cells. The number of seminiferous tubules with lumens with elongated spermatids present was counted. The magnification used did not allow identification of myoid cells that were in close proximity to the basement membrane of the seminiferous tubules. The cell mass outside of the basement membrane of the seminiferous tubules, other than vasculature and relatively small mass myoid cells, is almost entirely composed of Leydig cells (Teerds, 1989).

Area measurements from the Bioquant system were used to calculate the percentage of the testis occupied by seminiferous tubules, the percentage of the testis occupied by seminiferous tubules with lumens, the percentage of the testis occupied by seminiferous tubules without lumens, the percentage of the testis occupied by vasculature, the percentage of the testis occupied by Leydig cells, and the percentage of tubules with lumens that had elongated spermatids present.

\section{Statistical Analyses}

Tests for normality were made on all traits for each line-age subclass using Proc Univariate (SAS, 1988). The distributions of the percentage of the testis occupied by seminiferous tubules with lumens and the percentage of the testis occupied by seminiferous tubules without lumens were found to have nonnormal properties (results discussed below).

A non-parametric test of differences, the WilcoxonMann-Whitney two-sample test (Steele and Torrie, 1980), was used for traits determined not to be normally distributed. Proc Rank (SAS, 1988) was used to rank the responses in ascending order for each age. Values with equal rank were assigned the mean of the corresponding ranks. Rank sums were calculated for each line at each age and used to test for line differences. The assumptions for this procedure are that samples from each line were random samples from their respective populations, that the samples from the two lines were mutually independent, and that samples from each line consisted of continuous random variables with a measurement scale that was at least ordinal (Conover, 1971).
Distributions of testis weight, epididymis weight, body weight, percentage of the testis occupied by seminiferous tubules, percentage of the testis occupied by vasculature, percentage of the testis occupied by Leydig cells, and percentage of seminiferous tubules with lumens that had elongated spermatids present did not deviate significantly from normal distributions. However, the variances for these traits differed across lines and ages $(P<.05)$ and increased proportionally to the means. Therefore, the weighted least squares procedure (SAS, 1988) was used for analyses of traits with heterogeneous variances. The weighting factor was the reciprocal of the subclass variances.

The statistical model for testis weight, epididymis weight, body weight, percentage of the testis occupied by seminiferous tubules, percentage of the testis occupied by vasculature and percentage of the testis occupied by Leydig cells included the effects of line, sire within line, age (linear, quadratic, cubic, and quartic), and the interaction of line with age. The statistical model for percentage of seminiferous tubules with lumens that had elongated spermatids included the effects of line, sire within line, age (linear, quadratic, and cubic), and the interaction of line with age. There were no boars with elongated spermatids present at $70 \mathrm{~d}$ of age, thus, there were fewer degrees of freedom for this trait.

\section{Results}

Data for body weight and weights of testes and epididymides for the boars used in this experiment are reported in a companion paper (Rathje et al., 1995). Because these data are pertinent to the interpretation of morphometric data, they are illustrated in Figure 1.

Boars of the TS line were heavier at each age than control boars, but the difference was not significant in Generation 8 (Figure 1, panel a). Rathje et al. (1995), however, found significant line differences in body weight in Generation 9, and Johnson et al. (1994) found significant correlated increases in body weights at Generation 10 in the select line. Differences between lines expressed as a percentage of the control ranged from $2 \%$ at $70 \mathrm{~d}$ to $5 \%$ at $160 \mathrm{~d}$. The cubic regression coefficient of weight on age was significant for both lines.

Differences between lines in weights of testes and epididymides were larger than differences in body weight (Figure 1, panels $\mathbf{b}$ and c). For weight of testes, the interaction between line and the quadratic effect of age was significant. Weight of testes in boars of the TS line increased more rapidly between 70 and $160 \mathrm{~d}$ than did testes in boars of line $\mathrm{C}$. The difference at $450 \mathrm{~d}$ was similar to that at $160 \mathrm{~d}$. The advantage for the TS line was $37 \%$ at $70 \mathrm{~d}, 120 \%$ at $100 \mathrm{~d}, 92 \%$ at $130 \mathrm{~d}, 40 \%$ at $160 \mathrm{~d}$, and $25 \%$ at $450 \mathrm{~d}$. 


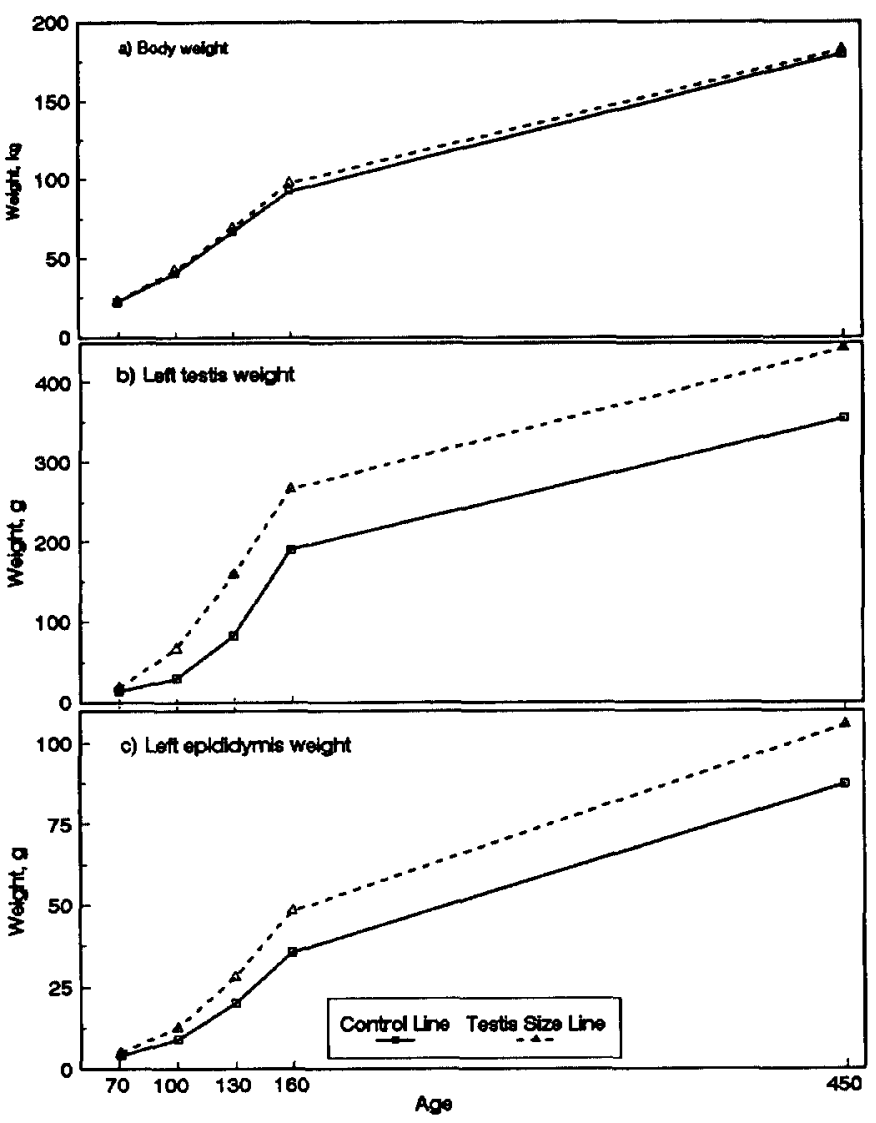

Figure 1. Body weight (a), left testis weight (b), and left epididymis weight (c) for boars of the control and testis size lines at $70,100,130,160$, and $450 \mathrm{~d}$ of age.

The effects of age and line on weight of epididymides were similar to effects on weight of testes. The interaction of line and quadratic effect of age was significant. The increase of the TS line compared with the $\mathrm{C}$ line was $17 \%$ at $70 \mathrm{~d}, 38 \%$ at $100 \mathrm{~d}, 39 \%$ at 130 $\mathrm{d}, 36 \%$ at $160 \mathrm{~d}$, and $21 \%$ at $450 \mathrm{~d}$.

Results of the Wilcoxon-Mann-Whitney Rank Sums Test for percentages of the testis occupied by seminiferous tubules with (TWL) and without (TWOL) lumens are in Table 1 . In boars of both lines, there was a rapid increase in TWL and a decrease in TWOL between 70 and $160 \mathrm{~d}$ of age (Figure 2, panels a and b), but these changes occurred earlier in the TS line. Mean TWL for line TS was significantly greater at 100 $\mathrm{d}(44$ vs $18 \%)$ and at $130 \mathrm{~d}$ ( 54 vs $43 \%$ ). Lines did not differ in TWL at 160 and $450 \mathrm{~d}$.

For TWOL, the mean for line $\mathrm{C}$ was significantly greater than for line TS at $100 \mathrm{~d}$ ( 25 vs $11 \%$ ). Lines did not significantly differ at $130 \mathrm{~d}$. Differences between means were small at $160(1.3 \%)$ and $450 \mathrm{~d}$ ( $2 \%$ ), but because boars of the TS line consistently ranked higher, differences in ranks at these ages were significant.

Lines differed $(P<.01)$ and the effect of age was cubic $(\mathrm{P}<.01)$ for percentage of the testis occupied by total seminiferous tubules, but the line $\times$ age interac- tion was not significant (Table 2). The least squares means are presented in Table 3 and are illustrated in Figure 2, panel c. Boars of the TS line had a greater percentage of the testis occupied by total seminiferous tubules from 70 to $160 \mathrm{~d}$. The advantage of the TS line was $23 \%$ at $70 \mathrm{~d}, 26 \%$ at $100 \mathrm{~d}, 14 \%$ at $130 \mathrm{~d}$, and $4 \%$ at $160 \mathrm{~d}$.

Significance levels for effects in the model for percentage of the seminiferous tubules with lumens and that contained elongated spermatids are presented in Table 2. Least squares means for this trait are presented in Table 3, and those means are illustrated in Figure 3, panel a. Elongated spermatids were not found in the testis of any boar at $70 \mathrm{~d}$ of age, but at all other ages, the mean for line TS was greater ( $P<.10$ for average line difference) than for line C. The mean percentage of tubules with elongated spermatids increased similarly with age in both lines. The effect of age was quadratic $(P=.06)$, but there was no interaction between line and age.

The decrease in percentage of tubules with elongated spermatids that occurred in both lines at $160 \mathrm{~d}$, compared with $130 \mathrm{~d}$, probably was not due to a reduction in actual sperm production. Rather, this decrease likely reflects the rapid increase in tubules with lumens that occurred at earlier ages, and some of these tubules could have been in an early stage of development in which spermatogenesis had not been completed.

Lines differed significantly in the percentage of the testis occupied by Leydig cells (Table 2 ). The effect of age on this trait was cubic $(P<.01)$, but line $\times$ age effects were not significant. Means were lower for the TS line between 100 and $160 \mathrm{~d}$, but line means were equal at 70 and $450 \mathrm{~d}$ (Table 3; Figure 3, panel b). Lower values for the TS line were not because there were fewer Leydig cells per testis. Testis weight and

Table 1. Results of the Wilcoxon-Mann-Whitney Rank Sums Test for the percentage of the testis occupied by seminiferous tubules with (TWL) and without (TWOL) lumens

\begin{tabular}{lccc}
\hline & & \multicolumn{2}{c}{ Rank sum } \\
\cline { 3 - 4 } Line $^{\mathrm{a}}$ & Age, d & TWL & TWOL \\
\hline $\mathrm{C}$ & 70 & 93.2 & 96.5 \\
TS & 70 & 96.0 & 92.0 \\
$\mathrm{C}$ & 100 & $128.6^{* *}$ & $224.7^{* *}$ \\
TS & 100 & 239.5 & 136.0 \\
$\mathrm{C}$ & 130 & $156.0^{*}$ & 173.6 \\
TS & 130 & 210.0 & 191.0 \\
$\mathrm{C}$ & 160 & 203.4 & $199.7^{*}$ \\
TS & 160 & 217.0 & 249.0 \\
$\mathrm{C}$ & 450 & 235.0 & $246.0^{*}$ \\
TS & 450 & 230.0 & 219.0 \\
\hline
\end{tabular}

${ }^{\mathrm{a}} \mathrm{C}=$ control line, $\mathrm{TS}=$ testis size line.

*Rank sums within age differ between lines, $P<.05$.

** Rank sums within age differ between lines, $P<.01$. 


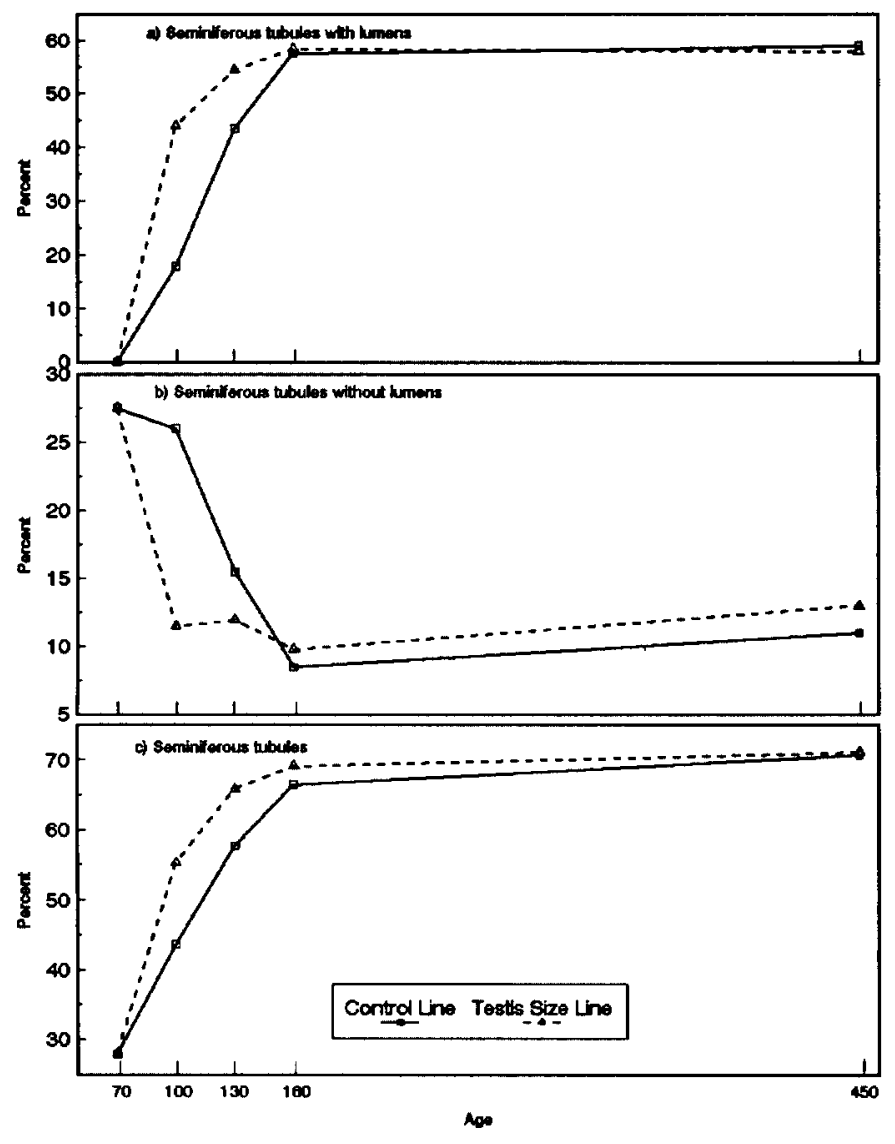

Figure 2. Percentage of the testis occupied by seminiferous tubules with lumens (a), without lumens (b), and percentage occupied by total seminiferous tubules (c) for boars of the control and testis size lines at $70,100,130,160$, and $450 \mathrm{~d}$ of age. total mass of Leydig cells were greater for the TS line than for the $\mathrm{C}$ line at each age. Because testis weight was substantially greater in the TS line, the total mass of seminiferous tubules and Leydig cells was greater in the TS line at each age despite the percentage of the testis occupied by Leydig cells being lower for the TS line.

A significant line $\times$ age interaction existed for percentage of the testis occupied by vasculature (Table 2). The mean was greater for line $\mathrm{C}$ at all ages except $160 \mathrm{~d}$ (Table 3 ). The increase in line $\mathrm{C}$, and the decrease in the TS line, from 70 to $130 \mathrm{~d}$ probably reflects the different testis growth rates for the lines. This was a period during which rate of testis growth was more rapid in the TS line, and if growth of the vasculature did not keep pace with proliferation of Sertoli and Leydig cells, the result we observed would occur. The C line had a lower rate of testis growth, and in this line, the increase in testis growth occurred later than in the TS line. Because vasculature is limited to the interstitial area (outside the tubules and predominantly composed of Leydig cells), the greater percentage vasculature in the $\mathrm{C}$ line probably reflects the greater volume percentage of Leydig cells present in the $\mathrm{C}$ line at 100 and $130 \mathrm{~d}$ of age.

\section{Discussion}

Lunstra et al. (1986) found that during the period of pubertal development in the boar, volume of individual Leydig cells was lowest at $100 \mathrm{~d}$, but increased rapidly to a maximum at ages between 130

Table 2. Mean squares and tests of significance for effects in the model for traits assumed to be normally distributed.

\begin{tabular}{|c|c|c|c|c|c|c|c|c|c|}
\hline \multirow[b]{3}{*}{ Effect } & \multirow[b]{3}{*}{ df } & \multicolumn{8}{|c|}{ Trait $^{a}$} \\
\hline & & \multicolumn{2}{|c|}{ ST, \% } & \multicolumn{2}{|c|}{ STWS, \% } & \multicolumn{2}{|c|}{ LC, \% } & \multicolumn{2}{|c|}{ Vas, $\%$} \\
\hline & & MS & $P$ & MS & $P$ & MS & $P$ & MS & $P$ \\
\hline Line & 1 & 21.6 & $<.01$ & 6.4 & .09 & $2,254.9$ & $<.01$ & 391.8 & $<.01$ \\
\hline Sire within line & 28 & 2.9 & $>.20$ & 2.3 & $>.20$ & 526.6 & $<.01$ & 31.3 & $<.01$ \\
\hline \multicolumn{10}{|l|}{ Age $^{b}$} \\
\hline $\mathbf{L}$ & 1 & 190.2 & $<.01$ & 134.2 & $<.01$ & $20,651.7$ & $<.01$ & 197.4 & $<.01$ \\
\hline $\mathrm{Q}$ & 1 & 223.4 & $<.01$ & 7.3 & .06 & $250,252.9$ & $<.01$ & 11.6 & $>.20$ \\
\hline $\mathrm{C}$ & 1 & 8.9 & $<.01$ & 4.2 & $>.20$ & $1,419.1$ & $<.01$ & 84.7 & $<.01$ \\
\hline $\mathrm{Qu}$ & 1 & .0 & $>.20$ & & & .0 & $>.20$ & 5.7 & $>.20$ \\
\hline \multicolumn{10}{|l|}{ Line $\times$ age } \\
\hline $\mathrm{L}$ & 1 & 1.1 & $>.20$ & .5 & $>.20$ & 163.6 & .20 & 135.1 & $<.01$ \\
\hline $\mathrm{Q}$ & 1 & .9 & $>.20$ & 2.0 & $>.20$ & 25.5 & $>.20$ & .0 & $>.20$ \\
\hline $\mathrm{C}$ & 1 & .7 & $>.20$ & .1 & $>.20$ & 379.8 & .12 & 247.8 & $<.01$ \\
\hline $\mathrm{Qu}$ & 1 & .6 & $>.20$ & & & 115.2 & $>.20$ & 27.4 & $>.20$ \\
\hline Residual & $-^{c}$ & 4.8 & & 2.4 & & 103.1 & & 16.4 & \\
\hline
\end{tabular}

${ }^{\text {a }} \mathrm{St}=$ percentage of the testis occupied by total seminiferous tubules, STWS = percentage of the testis occupied by seminiferous tubules with elongated spermatids present in lumens, $\mathrm{LC}=$ percentage of the testis occupied by Leydig cells, and Vas = percentage of the testis occupied by vasculature.

${ }^{\mathrm{b}} \mathrm{L}=$ linear, $\mathrm{Q}=$ quadratic, $\mathrm{C}=$ cubic, and $\mathrm{Qu}=$ quartic effect of age.

$\mathrm{c}_{\mathrm{df}}=105$ for ST, 77 for STWS, and 95 for LC and Vas. 
Table 3. Least squares means and standard errors (SE) for traits assumed to be normally distributed

\begin{tabular}{lccccc}
\hline & & \multicolumn{4}{c}{ Trait $^{\mathrm{a}}$} \\
\cline { 2 - 6 } Line & Age, d & ST, \% & STWS, \% & LC, \% & Vas, \% \\
\hline C & 70 & $27.9 \pm 2.0$ & - & $68.4 \pm 2.0$ & $3.7 \pm .8$ \\
TS & 70 & $28.1 \pm 2.5$ & - & $68.6 \pm 2.8$ & $3.3 \pm .9$ \\
C & 100 & $43.7 \pm 2.1$ & $14.2 \pm 4.7$ & $54.4 \pm 2.0$ & $4.9 \pm .8$ \\
TS & 100 & $55.3 \pm 2.6$ & $20.4 \pm 4.2$ & $42.1 \pm 2.1$ & $2.6 \pm .9$ \\
C & 130 & $57.7 \pm 3.1$ & $32.3 \pm 7.8$ & $36.8 \pm 2.9$ & $5.5 \pm .7$ \\
TS & 130 & $65.9 \pm 3.0$ & $49.5 \pm 8.8$ & $32.5 \pm 2.8$ & $1.6 \pm .8$ \\
C & 160 & $66.5 \pm 1.8$ & $27.7 \pm 4.7$ & $31.1 \pm 1.7$ & $2.4 \pm .5$ \\
TS & 160 & $69.1 \pm 2.9$ & $47.7 \pm 5.3$ & $28.2 \pm 2.6$ & $2.7 \pm .6$ \\
C & 450 & $70.7 \pm 2.5$ & $64.6 \pm 10.2$ & $26.7 \pm 2.3$ & $2.5 \pm .3$ \\
TS & 450 & $71.1 \pm 2.0$ & $81.3 \pm 12.2$ & $26.7 \pm 1.8$ & $2.2 \pm .4$ \\
\hline
\end{tabular}

${ }^{\text {a }} \mathrm{ST}=$ percentage of the testis accupied by total seminiferous tubules, STWS = percentage of the testis occupied by seminiferous tubules with elongated spermatids present in lumens, LC = percentage of the testis occupied by Leydig cells, and Vas = percentage of the testis occupied by vasculature

and $160 \mathrm{~d}$. However, volume percentage of Leydig cells in the testes were maximum $(45 \%)$ at $70 \mathrm{~d}$ and then declined to a value of $10 \%$ at $220 \mathrm{~d}$, even though total weight of Leydig cells increased to a maximum at 160 $\mathrm{d}$ and changed little thereafter (Allrich et al., 1983). Similar results were found by van Stratten and Wensing (1978). Even though total mass of Leydig cells increased during pubertal development, the volume percentage in the testes declined because development of seminiferous tubules was very rapid. Allrich et al. (1983) found testes volume percentage of seminiferous tubules increased steadily from 70 to 190 $d$ of age, but did not change thereafter. The largest increase occurred between 100 and $130 \mathrm{~d}$.

Our results are similar to those discussed above and agree with changes in testicular development and seminiferous tubule diameter with age reported by van Stratten and Wensing (1977). In both lines, development of seminiferous tubules was very rapid between 70 and $160 \mathrm{~d}$ (Figure 2), and volume percentage of the testes occupied by Leydig cells declined sharply from 70 to $160 \mathrm{~d}$ of age (Figure 3 ). These events occurred more rapidly and earlier in the TS line. Therefore, selection for predicted weight of testes at $150 \mathrm{~d}$ of age also selected for earlier initiation of the events within the testes that lead to puberty. These events lead to production of elongated spermatids and release of spermatozoa into the lumen of the seminiferous tubules. No elongated spermatids were found in tubules of 70-d-old boars of either line, but at all other ages a higher percentage of the seminiferous tubules of boars of the TS line contained elongated spermatids and the increase in means with age was more rapid in the TS line (Figure 3 ). Although the exact age at puberty could not be determined for each boar, the appearance of elongated spermatids occurred earlier in the TS line and we conclude that selection significantly reduced age at puberty in the TS line.

Boars of the TS line had more rapid growth of testes during pubertal development than boars of the $\mathrm{C}$ line and the phase of rapid testicular growth occurred at an earlier age (Figure 1). Body weights also were heavier for the TS line after $70 \mathrm{~d}$ of age, but the

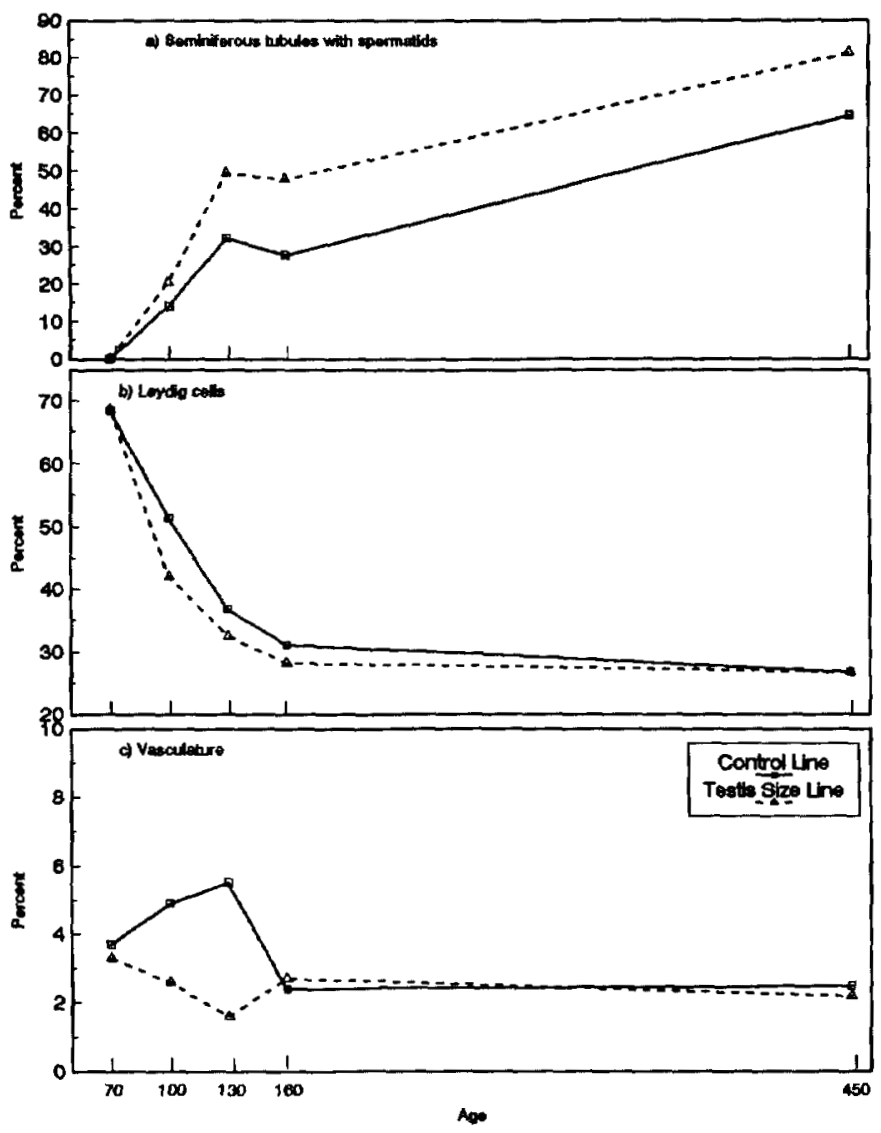

Figure 3. Percentage of the testis occupied by seminiferous tubules with lumens that contained elongated spermatids (a), Leydig cells (b), and vasculature (c) for boars of the control and testis size lines at 70, 100, 130,160 , and $450 \mathrm{~d}$ of age. 
interaction between line and age for body weight was not significant. Therefore, the two lines differed significantly in growth rate of testes but had similar patterns of body growth. These results agree with those reported by Allrich et al. (1983), who found that within ages, weights of testes and epididymides were not significantly correlated with body weight, and concluded that body weight is not a primary factor controlling growth of testes.

Correlations between .5 and .65 between weight of testes and daily sperm production have been reported in the bull (Almquist and Amann, 1961; Amann, 1970) and in the boar (Fent et al., 1983; Schinckel et al., 1983; Toelle et al., 1984; Young et al., 1986). The large differences in weight of testes between the TS and the $\mathrm{C}$ line explain most of the advantages in total daily sperm production for boars of the TS line reported by Rathje et al. (1995). However, these researchers also found more sperm produced per gram of testicular tissue for boars of the TS line in samples of testicular tissue from the same boars studied in this experiment.

\section{Implications}

Selection for predicted weight of testes at $150 \mathrm{~d}$ was effective and resulted in younger age at puberty of boars. The implications for the swine industry are not clear. Earlier puberty would be beneficial if younger boars are fertile and can be used successfully as breeders. Experiments are now underway to determine whether boars of the testis size line produce more semen per ejaculate, and can have semen collected at younger ages and at more frequent intervals than boars of the castrate line. When these data are available, potential application of this selection method can be more clearly stated.

\section{Literature Cited}

Allrich, R. D., R. K. Christenson, J. J. Ford, and D. R. Zimmerman. 1983. Pubertal development of the boar: Age-related changes in testicular morphology and in vitro production of testosterone and estradiol-17 $\alpha$. Biol. Reprod. 28:902.

Almquist, J. O., and R. P. Amann. 1961. Reproductive capacity of dairy bulls. II. Gonadal and extragonadal sperm reserves as determined by direct counts and depletion traits; dimensions and weight of genitalia. J. Dairy Sci. 44:1668.

Amann, R. P. 1970. Sperm production rates. In: The Testis. A. D. Johnson, W. R. Gomes, and N. L. Van Demark (Ed.). Vol 1. p 433. Academic Press, New York.
Conover, W. J. 1971. Practical Nonparametric Statistics. John Wiley and Sons Inc., New York.

Coulter, G. H., and R. H. Foote. 1979. Bovine testicular measurements as indicators of reproductive performance and their relationship to productive traits in cattle: A review. Theriogenology 11:297.

Fent, R. W., R. P. Wettemani, and R. K. Johnson. 1983. Breed and heterosis effects on testicular development and endocrine function of puberal boars. J. Anim. Sci. 57:425.

Gipson, T. A., D. W. Vogt, J. W. Massey, and M. R. Ellersieck. 1985. Association of scrotal circumference with semen traits on young beef bulls. Theriogenology 24:217.

Glauert, A. M. 1975. Fixation, dehydration, and embedding of biological specimens. In: Practical methods in electron microscopy. A. M. Glauert (Ed.). pp 73-110, North-Holland Pub., New York.

Haley, C. S., G. J. Lee, M. Ritchie, and R. B. Land. 1990. Direct responses in males and correlated responses for reproduction in females to selection for testicular size adjusted for body weight in young male lambs. J. Reprod. Fertil. 89:383.

Johnson, R. K., G. R. Eckardt, T. A. Rathje, and D. K. Drudik. 1994. Ten generations of selection for predicted weight of testes in swine: Direct response and correlated response in body weight, backfat, age at puberty, and ovulation rate. J. Anim. Sci. 72 : 1978.

Johnson, L., and W. B. Neaves. 1981. Age-related changes in the Leydig cell population, seminiferous tubules, and sperm production in stallions. Biol. Reprod. 24:703.

Luft, J. H. 1961. Improvements in epoxy resin embedding methods. J. Biophys. Biochem. Cytol. 9:409.

Lunstra, D. D., J. J. Ford, and S. E. Echternkamp. 1978. Puberty in beef bulls: Hormone concentrations, growth, testicular development, sperm production and sexual aggressiveness in bulls of different breeds. J. Anim. Sci. 46:1054.

Lunstra, D. D., J. J. Ford, R. K. Christenson, and R. D. Allrich. 1986. Changes in Leydig cell ultrastructure and function during pubertal development in the boar. Biol. Reprod. 34:145.

Rathje, T. A., R. K. Johnson, and D. D. Lunstra. 1995. Sperm production in boars after nine generations of selection for increased weight of testis J. Anim. Sci. 73:2177.

SAS. 1988. User's Guide. Statistics: SAS Inst. Inc., Cary, NC.

Sato, T., and M. Shamoto. 1973. A simple rapid polychrome stain for epoxyembedded tissue. Stain Technol. 48:223.

Schinckel, A., R. K. Johnson, R. A. Pumfrey, and D. R. Zimmerman. 1983. Testicular growth in boars of different genetic lines and its relationship to reproductive performance. J. Anim. Sci. 56: 1065.

Steel, R.G.D., and J. H. Torrie. 1980. Principles and Procedures of Statistics with Special References to the Biological Sciences. McGraw-Hill Book Co., New York.

Teerds, K. J. 1989. Aspects of Leydig cell development in the rat testis. Ph.D. Thesis. Drukwerk, The Netherlands.

Toelle, V. D., B. H. Johnson, and O. W. Robison. 1984. Genetic parameters for testes traits in swine. J. Anim. Sci. 59:967.

van Stratten, H.W.M., and C.J.G. Wensing. 1977. Histomorphometric aspects of testicular morphogenesis in the pig. Biol. of Reprod. 17:467.

van Stratten, H.W.M., and C.J.G. Wensing. 1978. Leydig cell development in the testis of the pig. Biol. of Reprod. 18:86.

Young, L. D., K. A. Leymaster, and D. D. Lunstra. 1986. Genetic variation in testicular development and its relationship to female reproductive traits in swine. J. Anim. Sci. 63:17. 